\title{
OPTIMALISASI FREKUENSI PEMBERIAN PAKAN KEONG BAKAU (TELESCOPIUM TELESCOPIUM) TERHADAP PERTUMBUHAN KEPITING BAKAU (SCYLLA SERRATA)
}

\section{OPTIMIZATION OF FREQUENCY OF GIVING BAKAU CONSO (TELESCOPIUM TELESCOPIUM) ON GROWTH OF SCABA CRAB (SCYLLA SERRATA)}

\author{
Fitri Suxes Sihite ${ }^{* 1}$, Cut Mulyani ${ }^{2}$, Andika Putriningtias ${ }^{3}$ \\ 1,3 Prodi Akuakultur Fakultas Pertanian Universitas Samudra, Aceh \\ ${ }^{2}$ Prodi Agroteknologi Fakultas Pertanian Universitas Samudra, Aceh \\ e-mail: fitrisihite123@gmail.com
}

\begin{abstract}
Abstrak: Pertumbuhan merupakan salah satu indicator dalam budidaya perikanan yang dilakukan dalam suatu kurun waktu, didalam budidaya perikanan terdapat syarat-syarat budidaya yang harus terpenuhi dengan baik, diantaranya adalah lingkungan perairan yang baik (kualitas air yang sesuai dengan kebutuhan ikan yang dibudidayakan), pakan yang diberikan sesuai, dan ikan yang dibudidayakan. Kepiting bakau (Scylla Serrata) merupakan salah satu komoditas perikanan yang bernilai ekonomis penting dan bernilai tinggi baik di pasaran. Salah satu faktor yang menunjang keberhasilan budidaya kepiting adalah ketersediaan pakan. Tujuan Penelitian ini adalah untuk mengetahui frekuensi pemberian pakan yang optimal terhadap pertumbuhan kepiting bakau (Scylla Serrata). Metode yang digunakan pada penelitian ini adalah metode eksperimental dengan 4 perlakuan dan 3 ulangan. Pada perlakuan 1 dengan frekuensi $2 x$ sehari, perlakuan 2 dengan frekuensi 3x sehari, pada perlakuan 3 dengan frekuensi 4x sehari, pada perlakuan 4 dengan frekuensi $5 x$ sehari. Hasil dari perlakuan tersebut berpengaruh tidak nyata terhadap kelangsungan hidup, laju pertumbuhan harian, efisiensi pakan, pertambahan berat mutlak, pertambahan panjang mutlak, sedangkan untuk parameter sintasan menunjukkan hasil yang tidak berpengaruh nyata. Laju pertumbuhan harian tertinggi terdapat pada perlakuan 3 sebesar 12,47\%, Pertambahan berat mutlak tertinggi terdapat pada perlakuan 3 sebesar 3,00 gr. Selanjutnya pada parameter pertambahan panjang mutlak yang tertinggi juga pada perlakuan 1 sebesar $4,22 \mathrm{~cm}$. Kemudian pada parameter efisiensi pakan menunjukkanhasil yang paling baik adalah pada perlakuan 2 dengan EP sebesar 61,70. Dari hasil tersebut dapat dinyatakan bahwa frekuensi pemberian pakan, memberikan pengaruh tidak nyata terhadap pertumbuhan kepiting bakau (Scylla Serrata).
\end{abstract}

Kata kunci : Scylla Serrata, frekuensi makan, pertumbuhan, keong bakau

\begin{abstract}
Growth is one indicator in aquaculture carried out in a period of time, in aquaculture there are cultivation requirements that must be met properly, including a good aquatic environment (water quality in accordance with the needs of fish being cultivated), feed provided accordingly, and fish are cultivated. Mangrove crabs (Scylla Serrata.) Are one of the fisheries commodities that have important economic value and high value in the market. One of the factors that support the success of crab culture is the availability of feed. The purpose of this study was to determine the optimal frequency of feeding on the growth of mangrove crabs (Scylla Serrata). The method used in this study is an experimental method with 4 treatments and 3 replications. In treatment 1 with a frequency of $2 x$ a day, treatment 2 with a frequency of $3 x$ a day, on treatment 3 with a frequency of $4 x$ a day, on treatment 4 with a frequency of $5 x$ a day. The results of these treatments have no significant effect on survival, daily growth rate, feed effiicency, absolute weight gain, absolute length increase, while the survival parameters show no significant effect. The highest daily growth rate was in treatment 3 of $12.47 \%$, the highest absolute weight gain was in treatment 3 of 3.00 gr. Furthermore, the highest absolute length increase parameter also in treatment 1 was $4.22 \mathrm{~cm}$. Then the parameter of feed efficiency showed the best results was in treatment 2 with an EP of 61.70. From these results it can be stated that the frequency of feeding gives no significant effect on the growth of mangrove crabs (Scylla Serrata).
\end{abstract}


Keywords: Scylla Serrata, feeding frequency, growth, mangrove snail

\section{PENDAHULUAN}

Kepiting bakau (Scylla Serrata) merupakan salah satu komoditas perikanan yang bernilai ekonomis penting dan bernilai tinggi, baik di pasaran dalam negeri maupun Luar negeri antara lain di Asia (seperti Singapura,, Thailand, Taiwan, Hongkong dan China), maupun di Amerika dan Eropa (Hanafi, 2009). Kebutuhan konsumen terhadap kepiting bakau sampai saat ini sebagian besar masih dipenuhi dari hasil penangkapan dialam yang sifatnya fluktuatif (Karim, 2013).

Permintaan kepiting terus mengalami peningkatan setiap tahunnya baik di pasaran dalam maupun luar negeri. Harga kepiting Indonesia dan konsumsi kepiting dunia yang tinggi memberikan peluang bagi Indonesia untuk mengekspor (Dewi dan Setiawina, 2015) sehingga menguntungkan dan layak untuk dikembangkan. Karena permintaan kepiting terus meningkat maka penangkapan di alampun semakin intensif pula dan terjadi kelangkaan populasi kepiting di perairan Indonesia.

Salah satu faktor yang menunjang keberhasilan budidaya adalah ketersediaan pakan (Anuar et al, 2011; Agus et al, 2014). Dalam pemberian pakan, salah satu hal yang perlu diperhatikan adalah frekuensi pemberian pakan. Frekuensi pemberian pakan sangat penting untuk dilakukan agar pembudidaya atau peneliti dapat mengetahui waktu pemberian pakan yang efisien (Siahainenia, 2008). Rendahnya kualitas pakan dapat mengakibatkan tingginya mortalitas pada stadia larva. Namun kegiatan pembenihan kepiting saat inimasih mengalami kendala yaitu ketersediaan benih yang tidak stabil akibat tingginya mortalitas (Effendy et al., 2005).

Keong bakau merupakan salah satu jenis gastrophoda yang memiliki cangkang. Keong bakau biasanya hidup di tanaman bakau dan juga di permukaan substrat maupun di dalam substrat. Keong bakau memiliki kandungan nutrisi yang baik yaitu beberapa jenis mineral mikro dan makro dalam jumlah yang sangat tinggi sehingga dapat digunakan sebagai pakan dalam budidaya kepiting. Mineral penting dalam keong bakau adalah natrium, kalium, fosfor, kalsium, magnesium dan selenium. Keong bakau memiliki kandungan protein 12 , $60 \%$, lemak $0,27 \%$, karbohidrat $13,45 \%$, kadar abu $1,77 \%$ dan kadar air 71,89\% (Iromo dan Kurnain, 2012).
Keong ini dianggap sebagai limbah pada budidaya udang atau kepiting tambak tradisional. Keong tersebut bersifat sebagai kompetitor yang turut memakan pakan alami dasar bagi hewan budidaya sehingga setelahpanen umumnya keong-keong yang ada ditambak dikumpulkan dan dibuang oleh petani tambak. Pemanfaatanya saat ini masih sebatas penggunaan cangkangnya sebagai pengeras jalan tambak sedangkan dagingnya dibiarkan membusuk.

\section{METODOLOGI}

Penelitian ini dilaksanakan di Green House Fakultas Pertanian Universitas Samudra. Bahan yang digunakan dalam penelitian ini adalah kepiting ukuran 100 gr dan keong bakau. Rancangan penelitian yang digunakan adalah rancangan Acak Lengkap (RAL) dengan 4 perlakuan dengan 3 kali ulangan. Dengan demikian, penelitian ini terdiri atas 12 percobaan. Adapun perlakuan yang diujikan yaitu perbedaan frekuensi pemberian pakan yaitu:F1 $=2 \mathrm{x}$ sehari $(06.00,18.00) \mathrm{F} 2=3 \mathrm{x}$ sehari $(06.00,14.00,22.00) \mathrm{F} 3=4 \mathrm{x}$ sehari $(06.00,12.00,18.00,22.00) \mathrm{F} 4=5 \mathrm{x}$ sehari $(06.00,10.00,14.00,18.00,22.00)$.

Sebelum kepiting uji ditebar terlebih dahulu ditimbang bobotnya dengan menggunakan timbangan dan diadaptasikan dengan kondisi lingkungan pemeliharaan selama 1 minggu. Benih kepiting diaklimatisasikan dalam waktu 1 minggu ke dalam setiap wadah sebanyak 3 ekor. Parameter yang diamati pada penelitian ini adalah sebagai berikut :

Sintasan kepiting bakau pada akhir penelitian dihitung menggunakan rumus Effendie (2003) sebagai berikut:

$$
\mathrm{SR}=\mathrm{x} 100 \%
$$

Keterangan :

$\mathrm{SR}=$ Survival Rate (\%);

$\mathrm{Nt}=$ Jumlah kepiting yang hidup pada akhir penelitian (ekor).

No = Jumlah kepiting yang hidup pada awal penelitian (ekor)

Laju pertumbuhan kepiting bakau dihitung berdasarkan rumus (Changbo et al., 2004) sebagai berikut:

$$
\text { SGR }=\underline{\text { In Wt }}
$$


Keterangan :

$\mathrm{SGR}=$ laju pertumbuhan harian (\%/hari).

$\mathrm{Wt}=$ Bobot rata-rata kepiting pada akhir penelitian (g).

Wo $=$ Bobot rata-rata kepiting uji pada awal penelitian (g).

$\mathrm{t}=$ Waktu penelitan (hari).

Pertumbuhan berat mutlak dihitung dengan rumus Effendie (1997):

$$
\mathrm{Wm}=\mathrm{Wt}-\mathrm{Wo}
$$

$\mathrm{Wm}=$ Pertumbuhan berat mutlak (gram), (gram),

Wo $=$ Berat biomassa pada awal penelitian (gram).

Pertambahan panjang mutlak dihitung dengan menggunakan rumus Effendie (1997):

$$
\mathrm{Pm}=\mathrm{Lt}-\mathrm{Lo}
$$

Keterangan:

$\mathrm{Pm}=$ Pertambahan panjang mutlak $(\mathrm{cm})$
Keterangan:

$\mathrm{Wt}=$ Berat biomassa pada akhir penelitian

Lt = Panjang rata-rata akhir $(\mathrm{cm})$

Lo $=$ Panjang rata-rata awal $(\mathrm{cm})$

Efisiensi pakan (EP) dihitung menggunakan rumus Takeuchi (1998), yaitu:

$\mathrm{EP}=\times 100 \%$

Keterangan:

EP : Efisiensi Pakan

Btm : Bobot tubuh kepiting uji yang telah mati (g)

F : Bobot total pakan yang dikonsumsi (g)

\section{HASIL}

Berdasarkan hasil analisis sidik ragam yang telah dilakukan menunjukkan hasil bahwa perlakuan optimalisasi frekuensi pemberian pakan keong bakau terhadap pertumbuhan kepiting bakau tidak berpengaruh nyata terhadap sintasan. Dari pengamatan kelangsungan hidup kepiting dapat dilihat pada lampiran 2. Rata-rata kelangsungan hidup kepiting akibat dari perlakuan frekuensi pemberian pakan dapat dilihat pada tabel 3.1..

Tabel 4.1 Kelangsungan hidup kepiting

\begin{tabular}{|c|c|}
\hline Perlakuan & Kelangsungan hidup \\
\hline F1 & 33,33 \\
\hline F2 & 33,33 \\
\hline F3 & 33,33 \\
\hline F4 & 33,33 \\
\hline
\end{tabular}

Pada tabel 4.1 menunjukkan bahwa kelangsungan hidup surrvival rate (SR) kepiting bakau menunjukkan bahwa pengamatan perlakuan F1- F4 memiliki persentase yang sama dengan nilai 33,33.

Pertumbuhan kepiting bakau yang di budidaya dengan melihat frekuensi pemberian pakan dapat diukur melalui pertambahan bobot tubuh dengan cara menimbang kepiting dengan satuan tertentu (Amalia, 2019). Laju pertumbuhan harian dapat digunakan sebagai cara untuk mengetahui bagaimana kemampuan kepiting tersebut tumbuh dan bertahan hidup selama berlangsungnya pemeliharan. Laju pertumbuhan harian dapat dilihat pada Gambar 3.2 berikut ini:
Pada tabel 3.2 perlakuan yang memiliki respon paling tinggi adalah pada frekuensi pemberian 4 x sehari (F3) sebanyak 12,47\%. Hal ini diduga frekuensi pemberian pakan sesuai dengan kebutuhan kepiting bakau, sehingga nutrisi tercukupi untuk mempertahankan kelangsungan hidupnya.

Hasil analisis menunjukkan dari setiap perlakuan frekuensi pemberian pakan tidak berpengaruh nyata terhadap parameter berat mutlak. Rata rata berat mutlak kepiting bakau dapat dilihat pada Gambar 3.3

\begin{tabular}{|c|c|}
\hline Perlakuan & Laju pertumbuhan harian \\
\hline F1 & 8,80 \\
\hline F2 & 9,06 \\
\hline F3 & 12,47 \\
\hline F4 & 8,67 \\
\hline
\end{tabular}


Tabel 3.3. Pertambahan berat mutlak

kepiting

\begin{tabular}{|c|c|}
\hline Perlakuan & Berat mutlak \\
\hline F1 & 1,67 \\
\hline F2 & 0,50 \\
\hline F3 & 3,00 \\
\hline F4 & 1,55 \\
\hline
\end{tabular}

Pada tabel 3.3 menunjukkan hasil pertambahan berat mutlak tubuh kepiting bakau selama pemeliharaan yang berbedabeda. Berdasarkan perbedaan frekuensi pemberian pakan yang diberikan, hal ini membuktikan bahwa dengan adanya perbedaan frekuensi pemberian pakan yang semakin tinggi tidak menentukan keberhasilan dalam pertambahan bobot dan berat tubuh kepiting. Setelah dilakukan uji Duncan dapat diketahui bahwa berat mutlak kepiting bakau memiliki respon paling tinggi adalah pada perlakuan dengan frekuensi pemberian pakan 4x sehari (F3) dengan nilai bobot mutlak sebesar 3,00 g. Sedangkan berat mutlak yang terendah pada perlakuan (F2)dengan frekuensi pemberian pakan $3 x$ sehari dengan nilai bobot mutlak sebesar 0,50 g.

Tabel 3.4 . Pertumbuhan panjang mutlak kepiting

\begin{tabular}{|c|c|}
\hline Perlakuan & Rata rata \\
\hline F1 & 4,22 \\
\hline F2 & 2,61 \\
\hline F3 & 2,72 \\
\hline F4 & 3,45 \\
\hline
\end{tabular}

Pada Tabel 3.4 menunjukkan bahwa pertumbuhan panjang mutlak menunjukan hasil yang berbeda beda. Dari pengamatan selama pemeliharaan pertumbuhan panjang mutlak tertinggi terdapat pada frekuensi pemberian pakan 2 x sehari yaitu mencapai $4,22 \%$, sedangkan panjang mutlak terendah terdapat pada perlakuan F2 dengan nilai panjang mutlak sebesar 2,61\%. Pada tabel 4.4 panjang mutlak F3 rendah dikarenakan panjang tidak berpengaruh besar dalam frekuensi pemberian pakan kecuali pada saat moulting.

Efisiensi pakan merupakan suatu perbandingan antara berat tubuh kepiting bakau dengan banyaknya pakan yang diberikan selama pemeliharaan. Semakin sedikit jumlah pakan yang diberikan maka semakin banyak pula kepiting memanfaatkan pakan yang diberikan (Sulawesty et al., 2014). Hasil analisis sidik ragam menunjukkan bahwa frekuensi pemberian pakan terhadap pertumbuhan kepiting bakau tidak memberikan pengaruh yang nyata $(\mathrm{P}>0,05)$. Berdasarkan hasil uji analisis sidik ragam untuk mengetahui perlakuan yang paling baik terhadap efisiensi pakan pada penelitian yang telah dilakukan mendapatkan hasil bahwa pada perlakuan (f3) 4x sehari memiliki nilai rasio yang terbaik, dikarenakan memiliki nilai rasio terendah dibandingkan dengan perlakuan lain. Selanjutnya untuk lebih jelas dapat dilihat pada Gambar grafik 4.5 dibawah:

Tabel 3.5. Efisiensi pakan

\begin{tabular}{|c|c|}
\hline Perlakuan & Efisiensi pakan \\
\hline F1 & 39,53 \\
\hline F2 & 46,78 \\
\hline F3 & 35,96 \\
\hline F4 & 37,55 \\
\hline
\end{tabular}

Berdasarkan tabel 3.5 perlakuan yang memiliki nilai efisiensi pakan paling tinggi adalah pada frekuensi pemberian F2 (3x sehari) sebanyak 61,70\%, selanjutnya pada frekuensi pemberian pakan F4 (5x sehari) sebanyak 61,06\%, selanjutnya frekuensi pemberian pakan pada F1 ( $2 x$ sehari) sebanyak 52,38\%. Sedangkan nilai efisiensi pakan paling rendah terdapat pada frekuensi pemberian pakan F3 (4x sehari) sebanyak
46,94\%. Perlakuan dengan frekuensi pemberian pakan kepiting bakau $3 \times$ sehari (F2) menghasilkan nilaiefisiensi pakanyang lebih tinggi dibandingkan dengan perlakuan lain. Efisiensi pakan digunakan untuk mengetahui seberapa besar efisiensi pakan yang diberikan selama pemeliharaan untuk dikonsumsi dengan baik, kemudian dikonversikan untuk menghasilkan pertumbuhan pada kepiting bakau. 


\section{PEMBAHASAN}

Pada perlakuan 1 sampai perlakuan 4 memiliki tingkat kelangsungan hidup yang tergolong rendah, hal ini dikarenakan adaptasi lingkungan kepiting tidak sesuai dengan habitat aslinya untuk keberlangsungan hidup kepiting bakau selama pemeliharaan. Selain itu terjadinya persaingan oleh organisme mikro seperti bakteri ataupun organisme lainnya yang masuk melalui celah- celah wadah. Hasil dari penelitian tersebut dapat dijelaskan bahwa perlakuan dari frekuensi pemberian pakan pada kepiting bakau memberikan efekyang buruk terhadap kepiting yang dibudidaya sehingga tidak mendukung kelangsungan hidup kepiting bakau secara maksimal (Mtile, 2009).

Penelitian yang dilakukan oleh Trino dan Rodrigues (2001) memperoleh sintasan 47-56\%, sedangkan Begum et al. (2009) memperoleh sintasan 86,25-93,75\%. Menurut penelitian Avelino et al. (1999) dalam Agus (2008), selain terjadi kompetisi yang dapat menyebabkan rendahnya angka kelangsungan hidup hewan uji, peluang sifat kanibalisme pun dapat menyebabkan kematian, terlebih jika dalam budidaya tersebut dicampur antara kepiting jantan dan betina sehingga frekuensi pemberian pakan tidak berpengaruh terhadap sintasan.

Tingginya laju pertumbuhan kepiting bakau pada perlakuan F3 yaitu $4 \times$ sehari diduga karena jumlah pemberian pakan $10 \mathrm{gr}$ sudah mencukupi untuk pertumbuhan yang optimal. Sedangkan pertumbuhan pada pemberian pakan 5 x sehari diduga pengosongan lambung kepiting lebih lama dibanding $4 \quad x \quad$ sehari sehingga dapat meningkatkan stres dan juga mortalitas. Hal ini

\section{KESIMPULAN}

Berdasarkan kajian yang telah dilakukan maka dapat disimpulkan bahwa:

Berdasarkan penelitian yang telah
dilakukan dapat disimpulkan bahwa:

\section{DAFTAR PUSTAKA}

Agus M. 2008. Analisis Carring Capacity Tambak pada Sentra Budidaya Kepiting Bakau (Scylla serrata) di Kabupaten Pemalang-Jawa Tengah. Tesis.Program Studi Magister Manajemen Sumberdaya Pantai Universitas Diponegoro, Semarang. sesuai penelitian Agus (2008) yang mengatakan bahwa dosis pemberian pakan sebesar 10\%/BB/hr sudah mencukupi kebutuhan energi untuk pertumbuhan. Pemberian pakan $4 \quad x$ sehari mencapai pertumbuhan optimal yang lebih cepat dibandingkan pemberian pakan 2 x sehari. Hal ini diduga karena pada perlakuan pemberian pakan $5 \mathrm{x}$ sehari tingkat stres kepiting lebih tinggi dibandingkan perlakuan pemberian $4 \mathrm{x}$ sehari.

Rendahnya pertumbuhan kepiting bakau pada perlakuan F2 dibandingkan dengan perlakuan lainnya diduga karena jumlah pakan yang diberikan tidak efektif untuk pertumbuhan. Hal ini sesuai dengan pernyataan Alamsyah dan Fujaya (2013) bahwa kepiting bakau akan tumbuh dengan baik apabila pakan tersedia dengan jumlah yang cukup dan mengandung semua unsur nutrien yang dibutuhkan dalam kadar yang optimal.

Gambar 4.4 menunjukkan hasil pertumbuhan panjang mutlak pada setiap perlakuan menunjukkan nilai yang berbedabeda. Hal ini dapat dinyatakan bahwa dengan adanya perlakuan semakin tinggi frekuensi pemberian pakan yang diberikan pada lingkungan (wadah budidaya) tidak mempengaruhi pertumbuhan panjang mutlak sehingga tingkat pertambahan bobot dan panjang tubuh kepiting belum tentu semakin besar. Pertumbuhan berat mutlak merupakan suatu hal yang paling mendasar dalam suatu budidaya. Apabila berat kepiting memiliki tingkat pertambahan maka akan sangat mempengaruhi laju pertumbuhan kepiting (Amalia, 2019)..

perbedaan frekuensi pemberian pakan keong bakau tidak berpengaruh nyata terhadap kelangsungan hidup kepiting bakau, laju pertumbuhan harian (LPH), pertambahan berat mutlak (PBM), pertambahan panjang mutlak (PPM), dan efisiensi pakan (EP).

Agus Putra A Samad, Nan Fan Hua, Lee Meng Chou. 2014. Effects of stocking density on growth and feed utilization of grouper (Epinephelus coioides) reared in recirculation and flow-through water system. African Journal of Agricultural Research. 9 (9): 812-822.

Amalia. R, Hastuti. S, Sudaryono. A. 2019. Pengaruh Pemberian tepung Cacing Tanah 
(Lumbricus sp.) Sebagai Atraktan Dalam Pakan Terhadap Tingkat Konsumsi Pakan, Efisiensi Pakan dan Pertumbuhan Ikan Patin (Pangasius pangasius.). Jurnal Sains Akuakultur Tropis, 3 (1) :27-35.

Anuar Hassan, Mohd Azmi Ambak, Agus Putra A Samad. 2011. Crossbreeding of Pangasianodon hypophthalmus (Sauvage, 1878) and Pangasius nasutus (Bleeker, 1863) and their larval development. Journal of Sustainability Science and Management. 6 (1): 28-35.

Aslamyah, Fujaya Y, S. 2013. Peningkatan Produksi dan Efisiensi Proses Produksi Kepiting Cangkang Lunak (Soft shell crab) Melalui Aplikasi Teknologi Industri Molting yang Ramah Lingkungan. Laporan Penelitian Tahun I, RAPID, DIKTI. Fakultas Ilmu Kelautan dan Perikanan, Universitas Hasanuddin, Makassar.

Aslamyah, S dan Y. Fujaya. 2014. Frekuensi Pemberian Pakan Buatan Berbasis Limbah Untuk Produksi Kepiting Bakau Cangkang Lunak. Jurnal Ilmu Kelautan dan Perikanan. 24 (1) : 44-52.

Avianto I, Sulistiono, I Setyobudiandi. 2013. Karakteristik Habitat Dan Potensi Kepiting Bakau (Scylla serrata, S. transquaberica, dan S. olivacea) Di Hutan Mangrove Cibako, Sancang, Kabupaten Garut Jawa Barat.JurnalIlmu Perikanan dan Sumberdaya perairan. Aquasains. 97-106 p.

Begum, M., M. M. R. Shah, A.A. Mamun and M. J. Alam. 2009. Comparative Study of Mud Crab (Scylla serrata) Fattening Practices Between Two Different Systems in Bangladesh. J. Bangladesh Agril. Univ. 7(1): 151156.

Budiman, A. 1988. Malacofauna of Halmaheran mangrove forets. Paper prepared for the report on "Species Biological Studies of Mangrove Ecosystem in East Indonesia", jurnal $15 \mathrm{pp}$

Dewi, M.D.K., \& Setiawina, N.D. (2015). Pengaruh kurs dollar, harga, dan Inflasi Terhadap Volume Ekspor Kepiting Indonesia. Jurnal Ekonomi Pembangunan, 4(7), 746-762.

Effendy.S.,Faidar.,Sudirman.,dan F,.Nurcahaya.2005. Perbaikan Teknik Pemeliharaan Larva Pada Produksi Massal Benih Rajungan (Portunus pelagicus). Penelitian Balai Budidaya Aair Payau Takalar.6:1-10

Fujaya, Y. E. Suryanti, E. Nurcahyono, dan N. Alam. 2008. Titer Ekdisteriod Hemolimph dan Ciri Morfologi rajungan (Portunus pelegicus) Selama Fase Molting dan Reproduksi. Jurnal Ilmu Kelautan dan Perikanan Universitas Hasanuddin. 18 (3) : 266-274.
Gunarso, W. 1985. Tingkah Laku Ikan dalam Hubungannya dengan Alat, Metode dan Teknik Penangkapan. Jurusan Pemanfaatan Sumberdaya Perikanan, Fakultas Perikanan - Institut Pertanian Bogor.

Hanafi, Mamduh M dan Abdul Halim, 2009, Analisis Laporan Keuangan, Edisi Keempat Cetakan Pertama, UPP.STIM YKPN, Yogyakarta.

Hamsiah. 2000. Peranan Keong Bakau (Telescopium telescopium L.) sebagai biofilter dalam pengelolaan Limbah budidaya tambak intensif. Tesis pada IPB

Houbrick R. S. 1991. Systematic review and functional morphology of the mangrove snails terebralia and telescopium (Potamididae prosobranchia). Malacologia33 (1-2): 289-338

Hubatsch H.A., Lee S.Y., Meynecke J.O., Diele K., Nordhaus I., Wolff M. 2015. Life-history, movement, and Habitat use of Scylla serrata (Decapoda, Portunidae): Current Knowledge and Future Challenges. Journal ofHydrobiologia 763:5-21.

Iromo, H. dan Kurnain, A. 2012. Pemanfatan keong Temberungun (Telescopium telescopium) sebagai pakan alternatif sebagaidan moulting kepitng bakau (Scyla serata). Tesis pada Universitas BorneoTarakan.

Juwana dan K. Romimohtarto. 2000. Rajungan, Perikanan, Cara Budidaya dan Menu Masakan. Djambatan. Jakarta.

Karim, M. Y. 2013. Kepiting Bakau (Bioekologi, Budidaya dan Pembenihannya). Penerbit Yarsif Watanpone, Jakarta.

Karim. M. Y. 2007. Pengaruh Osmotik pada Berbagai Tingkat Salinitas Media terhadap Vitalitas Kepiting Bakau (Scylla olivacea) Betina. Jurnal Protein. 14(1): 65-72.

Kasry, A. 1996. Budidaya Kepiting Bakau dan Biologi Ringkas. Bharata, Jakarta. 93 p.

KKP [Kementrian Kelautan dan Perikanan]. 2010. Program peningkatan produksi budidaya tahun 2010-2014. Di dalam: Forum Akselerasi Pembangunan Perikanan Budidaya 2010, Batam 25-28 Januari 2010.

Kordi, G.H. 1997. Budidaya Kepiting dan Ikan Bandeng di Tambak Sistem Polikatur. Dahara Press. Semarang.

Kumlu, M. Kir. 2005. Food Consumption, Moulting, and Survival of Penaeus semiculatus During Over-Wintering. Aqua.Res., 366:137:143

Kuntiyo, A. Zainal, dan Supratno . 1993. Pedoman budidaya Kepiting Bakau (Scylla serrata) Di Tambak Balai Budidaya Air Payau. Jepara.

Kuntiyo, Arifin Z, Supratomo T. 1994. Pedoman Budidaya Kepiting Bakau (Scylla serrata) 
di tambak. Direktorat Jenderal Perikanan, Balai Budidaya Air Payau, Jepara.

Mardjono, M. 1994. Pedoman Pembenihan Kepiting Bakau. Direktorat Jendral Perikanan, Balai Budidaya Air Payau, Jepara.

Mirzards.2009. Pengemasan Daging Rajungan Pasteurisasi dalam Kaleng. Skripsi. Fakultas Perikanan Ilmu Kelautan. Institut Pertanian Bogor. Bogor

Moosa, M.K., I. Aswandy dan A. Karsy. 1985. Kepiting Bakau-Scylla Serrata (Forskal) Dari Perairan Indonesia . LON-LIPI. Jakarta.

Muchtadi, T dan Sugiyono. 1989. Ilmu Pengetahuan Bahan Pangan. IPB-Press. Bogor.

M. Mtile. 2009. A Preliminary Study on The Response of Mangrove Mud Crab (Scylla serrata) to Different Feed Types Under Drive-in Cage Culture System. Journal of Ecology and Natural Environment Vol. 1(1): 7-14.

Nontji A. 1993. Laut Nusantara. Jakarta: Djambatan, Nugroho. $\mathrm{T}$ dan Zahid. M. $2009 . \quad$ Ekobiologi dan potensipengembangan rajungan Indonesia. Institut Pertanian Bogor. Bogor.

Rusdi I., Karim M. Y. 2006. Salinitas Optimum bagi Sintasan dan Pertumbuhan Crablet Kepiting Bakau (Scylla paramamosain). Sains \& Teknologi, Vol.6 No.3 : 149-157. Fakultas Ilmu Kelautan dan Perikanan, Universitas Hasanuddin. Makasar.

Saanin, 1984. Taksonomi dan Kunci Identifikasi Ikan Volume I dan II. Bina Rupa Aksara. Jakarta.

Setiawati, 2013. Tumbuhan Bahan Pestisida Nabati dan Cara pembuatannya Untuk Pengendalian Organisme Pengganggu (OPT). prima Tani Balista: bandung.

Sheen, S.S. and S.W. Wu. 1999. The effect of dietary lipid levels on the growth response of juvenil mud crab Scylla serrata. Aquaculture 175: 143-153. Siahainenia, L. 2009. Struktur Morfologis Kepiting Bakau (Scylla serrata ). Jurnal Triton. 5(1):11-21.

Siahainenia L. 2008. Bioekologi Kepiting Bakau (Scylla serrata.) di Ekosistem Mangrove Kabupaten Subang, Jawa Barat. Disertasi [tidak dipublikasi]. Bogor: Sekolah Pascasarjana, Institut Pertanian Bogor. $246 \mathrm{hlm}$.

Sugama K, Waspada, Tanaka H. 1986. Pertumbuhan beberapa jenis ikan beronang (Siganus sp.) dalam kurungkurung Apiung.

Sulaiman dan Hanafi, 1992. Pengaruh pemotongan tangkai mata terhadap kematangan gonad dan pertubuhan kepiting bakau (Scylla serrata). Pen. Budidaya Pantai, 8(4): 55-62.

Sulawsety. F, Chrismandha. T, Mulyana.E. 2014. Laju Pertumbuhan Ikan Mas (Cyprinus carpio L) Dengan Pemberian Pakan Lemna (Lemna perpusilla torr.) Segar Pada Kolam Sistem Aliran Tertutup. Pusat Penelitian Limnologi-Lipi

Susanto, H. 2008. Budidaya ikan di pekarangan. Penebar swadaya, Jakarta 152 hlm.,. 2005. Pertumbuhan krablet rajungan (Portunus pelagicus) turunan I (F-1) dengan jenis pakan berbeda. Dalam Sudradjat et al (Eds) Buku perikanan budidaya berkelanjutan. Pusat Riset Perikanan Budidaya Badan Riset Kelautan dan Perikanan. Hal 187 - 186.

Susanto, B., I. Setyadi, Haryanti, dan A. Hanafi. 2008. Pedoman Teknis Teknologi Perbenihan Rajungan (Portunus pelagicus). Pusat Riset Perikanan Budidaya. Badan Riset Kelautan dan Perikanan. Departemen Kelautan dan Perikanan. Jakarta. 22 pp.

Tahmid, M. 2016. Kajian Ekologi-Ekonomi Kepiting Bakau (Scylla serrata Forskal, 1775) di Ekosistem Mangrove Teluk Bintan Kabupaten Bintan.Skripsi. Institut Pertanian Bogor.Bogor.

Trino, A.T., O.M. Millamena \& C. P. Keenan. 2001.

Wahyurini, E. T. 2014. Pengaruh Kombinasi Suhu dan Salinitas Terhadap Kematangan Telur Kepiting Bakau (Scylla Serrata Forskal) di Bak-bak Percobaan. Jurnal Manajemen Agribisnis. 14 (2).

Wicoksono, D. L., M. Zainuri dan Widianingsih. 2014. Pengaruh Pemberian Pakan Alami Yang Berbeda Terhadap Pertumbuhan Kepiting Soka di Tambak Desa Mangunharjo Kecamatan Tugu. Journal of Marine Researh. 3 (3) : 265-273.

Yasin H. 2011. Pengaruh pemberian berbagai kadar karbohidrat dan lemakpakan bervitamolt terhadap efisiensi pakan dan pertumbuhan kepiting bakau (Scylla serrata.). Skripsi. Fakultas Ilmu Kelautan dan perikanan Jurusan Perikanan, Universitas Hasanuddin, Makassar. 19 pp.

Zatnika, A. 2009. Pedoman Teknis Budidya Rumput Laut. Badan Pengkajian dan Penerapan Teknologi. Jakarta. 